\title{
Katarzyna Miszczak
}

Wroclaw University of Economics and Business

e-mail: katarzyna.miszczak@ue.wroc.pl

ORCID: 0000-0001-6158-9339

\section{BUILDING NEW INSTITUTIONAL CAPACITY OF POLISH CITIES}

\section{BUDOWANIE NOWEJ ZDOLNOŚCI INSTYTUCJONALNEJ POLSKICH MIAST}

\author{
DOI: $10.15611 /$ br.2019.1.10 \\ JEL Classification: H70, O10, O20, P25, P35, R00, Z10
}

\begin{abstract}
Summary: The article presents selected issues related to building the institutional capacity of Polish cities in light of contemporary challenges in the field of urban renewal and improving the quality of urban space based on attracting human, social and creative capital. The research purpose is the identification and characterization of the main features and problems of the functioning of the urban institutional system in Polish realities, in which the integrated territorial approach, participation and effective implementation of learning processes should constitute the essential elements of the innovative institutional potential of urbanized units. One of the important research findings presented in the article is the statement that strengthening the institutional capacity of Polish cities by building different organizational forms, characterized by decentralization, multifaceted management, networking, innovation, creativity and an eco-friendly approach, sets the framework for a new urbanity.
\end{abstract}

Keywords: institutional capacity, urban space, local government administration, participation, social and creative capital.

Streszczenie: W artykule przedstawiono wybrane zagadnienia dotyczące budowania zdolności instytucjonalnej polskich miast $\mathrm{w}$ świetle współczesnych wyzwań $\mathrm{w}$ zakresie odnowy miast oraz poprawy jakości przestrzeni miejskiej opartej na atrakcyjnym kapitale ludzkim, społecznym i kreatywnym. Celem badawczym jest identyfikacja i charakterystyka głównych cech i problemów funkcjonowania miejskiego systemu instytucjonalnego w polskich realiach, w którym zintegrowane podejście terytorialne, partycypacja oraz skuteczna implementacja procesów uczenia się stanowić powinny zasadnicze elementy innowacyjnego potencjału instytucjonalnego jednostek zurbanizowanych. Jednym z istotnych wniosków badawczych zaprezentowanych w artykule jest stwierdzenie, iż wzmocnienie zdolności in- 
stytucjonalnej polskich miast poprzez budowanie odmiennych form organizacyjnych, charakteryzujących się decentralizacją, wielopłaszczyznowym zarządzaniem, usieciowieniem, innowacyjnością, kreatywnością i podejściem eco-friendly, wyznacza ramy nowej miejskości.

Słowa kluczowe: zdolność instytucjonalna, przestrzeń miejska, administracja samorządowa, partycypacja, kapitał społeczny i kreatywny.

\section{Introduction}

The variety of problems and mechanisms of shaping urban space in the 21 st century determines the need to overcome old thinking patterns and to integrate the action of many stakeholders, taking into account the contemporary development challenges of cities, including depopulation, civilization diseases, social exclusion, degradation of the environment and urban landscape, congestion, growing crime rate, climate change and industry crises. Cities currently characterized by varying levels of resilience are more or less sensitive to various types of shocks, pressures and distortions that deform or in extreme cases destroy the existing social, economic or spatial structures. Some of them can effectively adapt to this kind of changes, while in the others structural changes lead to stagnation and regression. Therefore, local institutions and communities exposed to various disasters should build resilience already at the stage of preparation activities and project works dedicated to the optimal and effective programming of urban development.

With regard to the above, the research question of the article is what are the main features and problems of the functioning of the urban institutional system in Polish realities and what are the opportunities of building the innovative institutional capacities of urbanized units in Poland? The essential elements constituting new institutional potential of cities are the integrated territorial approach, and the participation and effective implementation of learning processes. In order to identify the current conditions of urban institutionalization, characterize its elements and answer the research questions, the following research methods were used: observational, statistical, source criticism, comparative and logical analysis.

The currently implemented 'third generation' urban policy is mainly focused on the intangible environment, i.e. stimulating and promoting network links between the entities and institutions functioning in cities. However, network relations between enterprises and scientific-research units are particularly important. Owing to that, in a situation of constantly changing external conditions and growing competition, these entities can retain the two most important advantages: economies of scale and flexibility conducive to their dynamism and innovation. The principle of dynamic development balancing should be taken as the overriding idea of a longterm strategy that integrates interdependent social, economic, political, technical and ecological processes occurring in the diverse geographical and geopolitical space of Poland. This creates the opportunity for a suspensive development process 
which minimizes the numerous contradictions and conflicts in the great game of permanent development and constant progress of civilization, as well as ensures the effective improvement of the life quality of contemporary and future generations by the proper shaping of the proportions among individual types of economic, human, social, creative and natural capital (Miszczak, 2017).

Moreover, there are greater chances of obtaining structural competitive ability in cities with an institutional set-up, such as (Hausner, 2001):

- organizational multiplicity and diversity, called "institutional density" after Amin and Thrift;

- the existence of coordination networks ensuring the cooperation of many functionally different organizations;

- the existence of rules and practices that protect competition.

The effectiveness adopted by city authorities of the development policy depends on whether the institutional system will be a stimulus or a limitation for intelligent city management. The institutional barrier appears when local government offices are not able to meet the expectations of local communities (or even suppress local initiatives) by introducing rules and procedures that hinder the community from all forms of social and economic activity (Broszkiewicz, 1997). Nevertheless, the authorities of Polish cities are increasingly following in the footsteps of local government institutions in highly developed countries, which attach great importance to the quality of their services. In this way, Polish municipal offices are able to effectively overcome institutional obstacles, ensuring that every citizen is served quickly and efficiently by a competent official (Dobrodziej, 2004, p. 234). The low quality of public institutions, the mismanagement of governance and the wrong directions of urban policy are the source of potential failure in the game for a smart, rich, green, open and friendly city.

\section{Institutionalisation of urban governance: some theoretical remarks}

The concept of "institution" is the basic category of economic thought known as institutionalism. However, institutional economics is not a well-established branch of economic sciences, but rather remains as a conglomerate of various schools and approaches (Sokołowicz, 2015, p. 74). In view of the above, a distinction should be made between 'old' and 'new' institutionalism. The 'old' trend interprets institutions in terms of building them through social relations (Hodgson, 1977, p. 253). Those representing 'old' institutional economics (including Thorstein Veblen, Herbert A. Simon, and today also Geoffrey M. Hodgson) criticize the model of rational homo oeconomicus, by recognizing habits, mentality and customs (treated in the categories of informal institutions) as hindering factors for free choice, but at the same time they are contributing to the creation of a stable social framework (Klimczak, 2005, pp. 15-17). 
On the other hand, 'new' institutional trends, above all the so-called New Institutional Economics (NIE), derive from the fundamental assumptions of neoclassical economics and they are defining institutions primarily as a limit for the behaviour of individual entities, striving mainly to maximize their own utility. NIE proponents, such as Douglas C. North, Olivier Williamson and Kenneth J. Arrow, emphasize the independence of choices and the freedom of action of the economic unit and indicate that this independence is limited only by institutions (Sokołowicz, 2015, p. 74), understood as sets of restrictive rules, norms hindering these activities (Ilnicka, 2004, p. 235). "Institutions are real enough, but they are not things that manifest themselves. [...] They are internalized orders, strict instructions that people follow and which will force the actions of others" (Okoń-Horodyńska, 1996, p. 16). In general, institutions involved in modern processes of city development can be divided into two groups (Ilnicka, 2004, pp. 238-239):

a) ones that have materialized organizations of a subjective character (e.g. city offices, development agencies, innovation centres, business incubators, technological parks, industrial and commercial chambers, consulting and training institutions, economic associations, banks and other financial and capital institutions, consulting companies, real estate offices, promotional centres, and also indirectly, universities, local political parties, social organizations, etc.);

b) institutions that are sets of norms and rules of conduct that do not have materialized organizations (e.g. tax systems, network relations, local culture).

Institutions play an important role in proper urban space management. This is manifested in initiating pro-development activities (e.g. supporting small and medium-sized companies), or intensifying already taken actions (e.g. as part of cooperation networks, local customs). They also have other various functions, including the following (Hausner, Kudłacz and Szlachta, 1997, pp. 21-22):

a) they dominate in innovation processes and technology transfers, often becoming an indispensable nexus in local and regional production processes;

b) they create local reality by implementing statutory tasks;

c) they transfer their own rationality of action to the rationality of behaviour of other institutions from local subjective system;

d) they stimulate local entrepreneurship and initiative.

The significant importance of institutional conditions in economic processes (although in most cases expressed implicitly) was already indicated in the literature of the 1940s. When Hungarian intellectual K. Polanyi was analysing in the Great Transformation (Polanyi, 1944) the evolution of capitalism from the time of the Congress of Vienna to the outbreak of World War I, he stated that the market and the society in which this market operates are interrelated. That is why capitalism needs social institutions in a special way (Patel, 2010, p. 24). One of the outstanding management specialists, Peter Drucker, also drew attention to similar issues. 
He wrote that the centre of social and economic problems of the modern world are not technologies or information capacity, but the institutions themselves (Drucker, 2002, pp. 39-40).

Numerous empirical studies conducted by proponents of neo-institutional economics confirm the existence of relationships between the quality of institutions, governance structures and economic growth (Alesina, 1998; Clague, 1997; Feng, 2003; Mauro, 1995; Knack and Keefer, 1995). Currently, governance is guided by the new logic of management and public as well as social activities, using the rule of cooperation and mobilization (Wojciechowski and Podgórniak-Krzykacz, 2007, p. 418). The development of a qualitatively different way of managing public affairs (including urban ones) is taking place in a new decision-making formula. The domination of interactivity especially promotes the co-governance process in the structure of interrelationships. Governance has a definitely social significance, that is illustrating self-organization, partner relations, a sense of common good (which is a shared city) and the impact of local communities on public decisions. Participants sharing in the creation of the coalition become learning entities (systems) that intelligently use and coordinate the potentials existing in the urban tissue.

The system of institutions which determines the efficiency of management as well as entrepreneurship and the creativity of the residents, has particular importance for the dynamics in urban development. In addition, appropriate institutional potential allows local government units to provide high-quality public services and effectively support the socio-economic development of local communities.

The concepts of institutional development and institutionalism have become somewhat synonymous with efforts to reform the public sector in many countries, including Poland. The need to reduce public expenditure while maintaining the current quality of public services and criticism of the traditional bureaucracy model imposes the obligation to search for alternative ways of organizing the public sector (including public administration) and develop new mechanisms for its operation. The new public management draws on the achievements of many concepts, among which the most important are: managerialism, market-oriented administration, entrepreneurial government and business-like management (Bober, Mazur, Turowski, and Zawicki, 2004, pp. 13-14).

The view that it is necessary to replace the traditional model of public administration (focused on procedures) by results-oriented administration and the belief that management instruments used in the private sector could be effectively used in the public sector ( the market approach) are common for the concepts mentioned above. The conditions for building a results-oriented administration are e.g.: a flexible staff policy, an implemented system of remuneration for officials based on performance criteria, a precise definition of the objectives and tasks of public institutions, as well as finding measures to assess their implementation. The following postulates should be also considered as common for the trends hidden behind the concept of new 
public management: decentralization of power, deregulation of monopolies, the withdrawal of the public authority from the direct actions of public services and using alternative mechanisms for their services, as well as creating quasi-markets of public service (Bober et al., 2004, p. 14). This approach also prefers taking control from bureaucracy and transferring it to local communities or integrating the activities of all sectors (public, private and social organizations sector) to build participatory management mechanisms (Osborne and Gaebler, 1994).

New models of governance, which refer to the experience of corporations, are one of the most important starting points for new thinking about cities and at the same time are one of the key conditions for an intelligent concept of urban policy (Miszczak, 2012b). However, the practical implementation of new models of governance requires special consideration. Particular attention should be paid to the consequences of spreading these systems outside the economic sphere for the dominant model of political power (Sörensen, 2005; Bovens, 2006). These consequences largely result from the relationship structure (network) and mechanisms facilitating its functioning (informal bonds, social capital) preferred in modern institutional systems. It should be also clearly emphasized that the effectiveness of new models of governance depends on actual, historically and culturally determined by institutional standards and the patterns of behaviour prevailing in particular cities or regions (Gąsior-Niemiec and Gliński, 2007) as well as the tools for the strategic management of these territorial units.

\section{Creating the environment for collective action}

In many Polish cities, the social aspect of the institutional system function is significantly weakened by the low quality of social capital manifested in the lack of mutual trust of various social groups, the limited self-organization of urban communities and the reluctance of residents to engage in public projects. The antidote to this state of affairs could be environments saturated with cross-linking processes in which horizontal, intense links between different entities can bring significant synergistic effects. Networks are also an important instrument of economic policy, especially when city authorities are switching from providing urban services to creating opportunities for various interest groups (Domański, 2002, p. 197). Networking processes cause a transition from places to space, where innovation propagates. As a consequence, clusters are created in the networks.

An efficiently operating local innovation system in the city space can contribute to the transformation of its functional structure (through the mutation or succession of one or many functions). The first element (consensus) requires the inclusion and cooperation of various public and private entities with different goals and interests. Synergy is a product of joint action, contacts and attempts to solve problems. 
The development of a network-type production system requires an extensive public-private partnership, where the private factor should be the leader, while the public factor should act as a catalyst for development. Examples of this production system type in Poland are: the printing cluster in Warsaw, the quasi-cluster of industrial automation in Gdańsk and the construction cluster in the Świętokrzyski region.

It is worth emphasising that building general and specialized cluster, i.e. one adapted to specific development conditions of a given infrastructure, organizing education and training programs, supporting research and development works at universities, focused on technologies directly or indirectly related to the area of the cluster's operation are the main signposts for actions undertaken by institutions that want to meet the requirements of today's competition. They should also (together with private entities) organize and co-finance a forum for meetings of network participants, promote and encourage collective actions to attract other key players, suppliers and service providers or create institutionalized forms of support such as technological or industrial parks oriented to the cluster's needs. In highly developed countries these activities have been undertaken for a long time and are bringing beneficial results (Walts, 1996, pp. 1-10). Japan can be an example, where the efficient operation of clusters is essentially based on the existence of large groups, so-called keiretsu, which are loosely connected, usually jointly owned shares, groups of companies. There is a bank in the centre of each keiretsu. These connections are important mainly as consultative bonds, which stimulates the formation of clusters.

The more the political and institutional system is pluralistic and the more clearly private and public actors are separated in it, the more likely the network will appear. Horizontal links operate more easily under complex policies, the implementation of which requires the use of many rare resources and is not coordinated only at central level. The aggregation of various fragmented interests allows to create networks because they help to organize them.

Polish cities that want to function effectively in international spatial economic networks should take into account new development conditions that can be enclosed in a triad of three supporting and highly interdependent phenomena: globalization - competition - innovation. The intense implementation of urban policy actions dedicated to making institutional governance more attractive requires the involvement of all stakeholders into the learning process. The form of networking between these entities undoubtedly opens up wider prospects for success in this regard. Meanwhile, this cooperation may be difficult due to the lack of compatibility between EU regulations and the institutional structures in a Member State. The result is that an organizational and institutional gap appears, and at the same time there is a need to adapt to new conditions (Börzel, 1999). Of course, the methods of this adaptation depend on the level of state authorities control and the applicable institutional culture in the country (an informal sense of the appropriate and inappropriate behaviour in a specific formal structure). However, this gap can be significantly reduced and 
the negative effects substantially weakened thanks to the principles of learning the economy paradigm that are included to the modernization process of the existing institutional system by decision-makers and local communities.

One of the most important elements increasing the effectiveness of urban policy is an integrated territorial approach, which integrates public activities to achieve the goals set for selected spatial units. This approach contributes to the better consideration of territorially different development conditions (potentials and problems) in the implementation of integrated, geographically and thematically focused public intervention. The inclusion of the integrated territorial approach in programming, management and the implementation of urban projects requires the coordination of various entities and results in the construction of an environment for collective actions to strengthen institutional capacity.

It is worth pointing out that increasing the institutional capacity of a city requires its authorities to constantly review and improve their strategic capabilities, organizational skills, professional knowledge in the design and implementation the research and innovation policy. In other words, it requires the dynamic involvement of local government representatives in the learning process. The most important change taking place in the economy is not the increased use of knowledge or widespread access to it, but the fact that knowledge becomes obsolete much faster and therefore needs to be updated so it stays in connection with reality (Lundvall, 2004). In this situation, cities or companies engage in learning and acquire new competences. The ability to gain new skills is very important for spatial units and entities operating in their areas. Furthermore, one can say that the basis for learning itself are globalization processes, changes in information technology and deregulation of markets, contributing to increased competitiveness and faster transformation. In a dynamically changing reality, people, organizations and cities are facing new problems, the solving of which requires new competences. Entities face difficult challenges in the transition to a learning economy. As a response, new organizational forms are created, which take into account more effective flat structures based on decentralization, multidirectional communication, innovation and networking.

The main declared goal of introducing new models of governance is to flatten traditional, hierarchical power structures in an effort to strengthen the efficiency and effectiveness of urban public policies. The less-well-considered aim is to subordinate public policies to market logic and give them competitiveness. One of the soft instruments that serve this strategy is the approval of social and economic partners to co-decide on public action programs. Another novelty is the assumed change in the operation rules of actors belonging to the sphere of politics and administration, which replace the culture of command and order with the culture of negotiation and persuasion (Heritier, 2002; Kohler-Koch, 2002). A much more tangible instrument is the systematic withdrawal of public actors to the positions of coordinator and initiator, possibly a co-investor and co-contractor of public action programs in the city, as well as the introduction of the competition principle for public resources, 
in which actors from the economic and social sphere participate on an equal footing with actors from the political sphere (Gąsior-Niemiec, 2008).

The most important task for all stakeholders of urban development, including various types of institutions, is not the detailed planning of knowledge acquisition processes, but rather the creation of favourable conditions enabling the involvement of as many urban economy entities as possible in the active learning process. The key element of knowledge management is to improve the learning ability of the business entity, and in consequence, particularly through networking, the creation of a learning organization. It should be also remembered that this management cannot limit the creativity of employees and local communities through excessive control, and is not hindered by employees of a higher level or representatives of local government. The skilful creation of institutional capacity is focused on people and the relationships between them, taking into account the learning process of individuals, groups and organizations (Lundvall, 2006).

The ability of the state to maintain public order, the efficient provision of public services, a responsible public service, independent judiciary and the central bank create the necessary conditions for the effective exercise of state power at all levels. These determinants also affect the prosperity of urban policy. An important category in achieving success in urban space management is performance, which is based on effective, efficient and partner development management in urban areas. The optimization of cooperation mechanisms in urban functional areas, the development of participation mechanisms and the dissemination of partner participation of society in urban development are particularly important. It is important to rebuild the capacity to develop degraded areas through comprehensive regeneration to support urban cohesion. Polish cities need to improve competitiveness and the ability to create development, including the labour market area. This goal is primarily served by investments, stimulating the growth of enterprises' innovativeness (thanks to R\&D cooperation), as well as strengthening the network cooperation of cities with other centres. However, development cannot be achieved at the expense of future generations. It is important to respect resources and manage them sustainably, including counteractions to chaotic suburbanization. Therefore, the emphasis is on sustainable investment with a preference for previously developed areas, so that city centres can fulfil their functions for the benefit of the residents. Another important task of urban policy in Poland is to support the development of subregional and local urban centres, primarily in problem areas of regional policy, by strengthening their functions, and preventing depopulation and economic decline. All cities are to be a good place to live, with access to high-quality health care, education, transport, culture and public administration services (Ministry of Infrastructure and Development, 2015). 


\section{The challenges of institutional development of urban space}

Nowadays, there is a growing awareness of the importance of institutions not only in explaining the course of socio-economic processes, but primarily in the context of explaining the differences in the level and speed of development in particular countries, regions and cities (Dominiak, Wasilczuk, and Starnawska, 2006, pp. 35-37). Using the assumptions of institutional economics we can look at economic growth and development also in relation to cities, from a non-standard approach, focusing mainly on traditional (resource and location) development factors. According to A.J. Scott "[...] economic development depends more on specific economic institutions and social norms occurring in the region (city) than on anonymous free market forces" (Scott, 1993). In the other category, i.e. social norms, customs, local culture, etc., cities in Poland have greater autonomy in its creation, conducting an appropriate, intelligent policy and undertaking intensive educational and promotional activities. However, when it comes to operating various types of institutions in the cities, they do not have the full right to self-determination. Cities are under the influence of central government authorities that sometimes introduce legal regulations regarding cities without recognizing or proposing optimal solutions for the functioning of these settlement units. This results in a weakening of the institutional potential in cities and as a consequence, the difficulties in the operationalization of the urban institutional system appear. The major problems with negative effects and requiring institutional changes are (Stawasz, 2017, p. 19):

a) uncontrolled urban sprawl, which is caused by the applied spatial planning system that allows for management according to the will of the owners (management of floodplains);

b) issuing location decisions dictated by developers;

c) appropriation of green areas;

d) protection of property rights without an appropriate reference to guarantee the public interest;

e) unequal, in relation to tasks, granting of funds to cities with different population and financial efficiency in terms of own income, imposing on cities subsequent tasks without adequate funding;

f) excessive protection of the residents' rights - tenants law, even when their rent is not paid;

g) unregulated matters of reprivatisation, leading to the recovery of tenements (sometimes by breaking the law) and leaving tenants without the help of the city authorities;

h) municipal housing resource management system (e.g. no action for housing exchange, insufficiently transparent municipal housing allocation system);

i) protracted tendering procedures, preferring the lowest project implementation price; 
j) insufficient debts collection;

k) deficiencies in the area of property insurance;

1) neglected areas requiring regeneration (buildings replacing railway infrastructure, city centres, following former industrial facilities), and above all the lack of knowledge and skills in managing such projects;

$\mathrm{m})$ relieving the next team of authorities from the assumptions and directions of actions proposed in the previous term, there is political rationality over economic rationality;

n) too restrictive law regarding historical objects.

Today's urban policy, which is a qualitatively different model based on the new development paradigm promoted by the OECD, departs from the traditional redistribution of funds in favour of strengthening and using endogenous potentials. It assumes a multi-sectoral (horizontal) approach to territorially oriented development, and thus the implementation of an integration system and the coordination of public policies with the economic policy objectives set for individual territories. To operate an efficient urban policy it is also necessary to take into account changes that are taking place in the modern economy such as: the rapid development and the great importance of ICT technologies, the new types of companies that are characterized by electronic commerce, the lack of trade unions and the founders' entrepreneurship.

However, the introduction of ICT without combining it with investment in training employees, management changes and changes in work organization, can have a negative impact on productivity growth. Simultaneous organizational changes and building advanced employee competences are needed to maximize the attractiveness of the institutional potential that exists in the cities.

The transformation of European, including Polish, cities into structures adapted to global challenges will require not only technological innovations, but also many social innovations - changes in thinking patterns and attitudes, changes in social practices and changes in institutions both at the workplace and more broadly in a social environment. The benchmarking approach will also need to be modified. Instead of treating benchmarking as a tool used mainly for comparing cities, they must be considered as a tool for gaining knowledge and learning. Cities have to start taking lessons from monitoring, evaluation and benchmarking. Therefore benchmarking should be transformed into bench-learning (Rousseau, 2008, p. 107). Actors in the field of the economy and policy makers in cities, who are facing different challenges, should take into account the requirements of competitiveness and the principles of sustainable development when it comes to planning and implementing action programs. This involves preventing local collapse and uncontrolled disasters that could even cover the entire world. A new global world focused on innovation is becoming less and less stable or "attached to the place." We must learn how to be carried away in a controlled way by a wave of continuous innovation that can have farreaching effects in the form of a "creative reconstruction" that radically and rapidly 
changes the situation of institutions, organizations and people (Rousseau, 2008, pp. 107-108). Responsibility for creating favourable conditions for development rests mainly with representatives of municipal authorities. They can stimulate the use of their potential, preserve local actors and leaders or determine desired development directions through modern strategic instruments.

Faced with the challenges of the 21 st century, the development of cities also depends on how effectively they can identify assets and mobilize all entities operating in their public spaces. Urbanized units should invest more than they have done so far in creating strategies and competences, especially those related to the needs diagnostics and the proper selection of projects. They should pay particular attention not just to the aspect of speed or formal correctness of spending, but to the real effects of project implementation. Urban decision-makers should also strive to develop and build efficient endogenous mechanisms to meet not only the current, but also the future, perhaps even more difficult, development challenges resulting from the comprehensive integration processes in Europe. The early building of appropriate institutional, substantive, methodological, scientific and their own development program is a condition for ensuring a significant competitive position for the city.

The foundation of thinking about the future of cities and, at the same time, one of the key conditions for the development of their institutional capacity is, in addition to the ones described above, the quality of human resources. This category refers to people as well as entire social groups, their skills, predispositions and ability to generate added value, in other words, it concerns the quality of broadly understood social and human capital.

In the case of small and medium-sized cities, good-quality living and working space is or will be largely determined by the satisfactory level of social and human capital. However, in the centre of interest for large cities and metropolises that offer access to high-quality human capital, advanced relational capital, infrastructure supporting researches and entrepreneurship, reliable transport and telecommunications infrastructure, competent public administration, and an attractive sphere of leisure time services and good living conditions, there is a new growth factor and intangible resource - creativity. This creativity, combined with the knowledge, skills and imagination of citizens in an atmosphere of broadly understood freedom, is something that determines the success of development initiatives which are taken in large urbanized units and encourages to settle and/or locate innovative activities. A creative city is considered as an integrated system of various organizations, cultures, operating in the environment of the public and private sectors or among social institutions. Therefore, the sustainability of a creative city is determined by (Scott, 2010): the institutional level of the local environment, social contracts, a system of shared standards, the scope of co-management and public-social-private partnership. As can be seen, the creativity and maturity of the institutional sphere manifest themselves as skills of the local environment to co-manage and efficiently implement common tasks, strengthen the institutional 
capacity of cities and contribute to the acceleration and optimization of urban space development processes. Intelligent urban policy should create good conditions for the construction spaces that are multifunctional, unscaled, friendly, attractive and safe for living and work, where users feel as responsible co-hosts.

\section{Summary and conclusions}

The contemporary challenges of the new urbanity (especially the demographic, infrastructural and climate) force individuals to build different organizational forms, characterized by decentralization, multifaceted management, networking, innovation, creativity and an eco-friendly approach (Miszczak, 2012a). An efficient, integrated and competitive institutional base is important for local development, including changes in the socio-economic structure of urbanized units. This means that as part of individual public policies implemented in urban space, the unique potential and competitive advantage of Polish cities and their districts should be best used to ensure sustainable social, economic and spatial development. Undoubtedly, the achievement of positive results in conducting an effective and smart urban policy is possible thanks to sufficiently high institutional capacity, which should be considered among public and private entities. The institutional capacity is built on efficiently functioning, stable and predictable institutions, capable of responding to social problems, open to dialogue and able to introduce new political, economic or spatial solutions. Investment in structures, human capital, system solutions and tools in the public sector are focused on more effective organizational processes, modern management and the creation of amotivated and qualified team of officials.

Cities that want to create their new competitive institutional capacity effectively and optimally fulfil the role of a node in international networks should have the following features (Jałowiecki, 2002, p. 42):

a) management, meaning the accumulation of capabilities and opportunities to develop strategic and decision-making functions at the highest level for enterprises and other institutions;

b) globality, meaning the achievement of a certain critical mass in terms of competence and services allowing for relative self-sufficiency, i.e. not using the help of better equipped centers;

c) resilience (resistance, flexibility), understood as the ability to maintain the level of development against disturbances (shock), a quick return to the level of development before disturbances, change of the city structure and achieve the previous (i.e. before disturbances) or a higher level of development.

Unfortunately, the multiple challenges and factors of city functioning coincide with the limited possibilities of public authority activities. A solution to this problem should be co-management and participation in horizontal coordination networks 
(Hausner, Zawicki, Mazur, and Kopyciński, 2008, p. 31). Success depends on the formation of an institutional interface between public authorities, enterprises, universities as well as research and development centres, which should be aimed at initiating new ways of communication, cooperation and financing of joint projects. This will contribute to the intensification of the generation and attraction of innovative human capital to cities. Furthermore it will help to implement the aspirations of decision-makers and residents of these areas to be an attractive settlement system based on knowledge and change its position in the international arena.

\section{References}

Alesina, A. (1998). The political economy of high and low growth (Annual World Bank Conference on Development Economics). Washington: World Bank.

Bober, J., Mazur, S. Turowski, B., and Zawicki, M. (Eds.). (2004). Rozwój instytucjonalny. Poradnik dla samorząów terytorialnych. Kraków: Wydawnictwo Małopolskiej Szkoły Administracji Publicznej Akademii Ekonomicznej w Krakowie oraz Ministerstwo Spraw Wewnętrznych i Administracji.

Börzel, T. A. (1999). Towards Convergence in Europe? Institutional Adaptation to Europeanization in Germany and Spain. Journal of Common Market Studies, 37(4).

Bovens, M. (2006), Analysing and Assessing Public Accountability. A Conceptual Framework (EUROGOV Papers, C-06-01).

Broszkiewicz, R. (1997). Bariery ograniczające rozwój gospodarki lokalnej. Prace Naukowe Akademii Ekonomicznej we Wroctawiu, (755), 31.

Dobrodziej, J. (2004). Uwarunkowania rozwoju lokalnego. In Z. Głuszczak, and A. Nowakowska (Eds.). Rozwój miast i regionów w procesie integracji europejskiej. Łódź: Zakład Ekonomiki Regionalnej i Ochrony Środowiska Uniwersytetu Lódzkiego.

Domański, R. (2002). Gospodarka przestrzenna. Warszawa: PWN.

Dominiak, P., Wasilczuk, J. E., and Starnawska, M. (2016). Przedsiębiorczość nieproduktywna w świetle ekonomii instytucjonalnej. Analiza zjawiska w Polsce. Warszawa: PWN.

Drucker, P. F. (2002). Management challenges for the 21st century. Oxford-New York-Tokyo: Butterworth-Heineman.

Feng, Y. (2003). Democracy, Governance and economic performance: Theory and evidence. Cambridge: MIT Press.

Gąsior-Niemiec, A. (2008). Rozwój regionalny w Europie: rola systemu rządzenia, kapitału społecznego i potencjału kulturowego. In P. Jakubowska, A. Kukliński, and P. Żuber (Eds.), Problematyka przyszłości regionów. W poszukiwaniu nowego paradygmatu. Forum Rozwoju Regionalnego i Polityki Regionalnej Regio Forum (t. 1). Warszawa: Wydawnictwo Ministerstwa Rozwoju Regionalnego.

Gąsior-Niemiec, A., and Gliński P. (2007). Europeanization of civil society in Poland. Revija za Socijalnu Politiku, 1(14).

Hausner, J. (2001). Modele polityki regionalnej w Polsce. Studia Regionalne i Lokalne, 1(5), 5-6.

Hausner, J., Kudłacz, T., and Szlachta, J. (1997). Instytucjonalne przesłanki regionalnego rozwoju Polski. Warszawa: PWN.

Hausner, J., Zawicki, M., Mazur, S., and Kopyciński, P. (2008). Raport pt. Dolny Ślask regionem wiedzy i innowacji. Wrocław: Fundacja Gospodarki i Administracji Publicznej. 
Heritier, A. (2002). Common Goods. reinventing European and international governance. New York, London: Rowman \& Littlefield Publishers, INC., Lanham, Boulder.

Hodgson, G. M. (1977). Economics and evolution: Bringing life back into economics. Ann Arbor: University of Michigan Press.

Ilnicka, M. (2004). Rola instytucji w procesie lokalnego rozwoju ekonomicznego. In Z. Głuszczak, and A. Nowakowska (Eds.), Rozwój miast i regionów w procesie integracji europejskiej. Łódź: Zakład Ekonomiki Regionalnej i Ochrony Środowiska Uniwersytetu Łódzkiego.

Jałowiecki, B. (2002). Zarzadzanie rozwojem aglomeracji miejskich. Białystok: Wydawnictwo Wyższej Szkoły Finansów i Zarządzania w Białymstoku.

Klimczak, B. (2005). Uwagi o powiązaniach między standardową ekonomią i nową ekonomią instytucjonalną. In S. Rudolf (Ed.), Nowa ekonomia instytucjonalna. Aspekty teoretyczne i praktyczne. Kielce: Wyższa Szkoła Ekonomii i Administracji im. prof. Edwarda Lipińskiego w Kielcach.

Knack, S., and Keefer, P. (1995). Institutions and economic performance: Cross country tests using alternative institutional measures. Economics and Politics, (7), 207-227.

Kohler-Koch, B. (2002). European networks and ideas: Changing national policies? EioP, 6. Retrieved 28.08.2019 from http://eiop.or.at/eiop/texte/2002-006a.html

Lundvall, B. A. (2004). Why the new economy is a learning economy? (Danish Research Unit for Industrial Dynamics Working Paper, 04-01, pp 18-23).

Lundvall, B. A. (2006). Knowledge management in the learning economy (Danish Research Unit for Industrial Dynamics Working Paper Working Paper, 06-06, pp. 3-5).

Mauro, P. (1995). Corruption and growth, Quarterly Journal of Economics, 110(3), 681-712.

Ministry of Infrastructure and Development. (2015). Krajowa Polityka Miejska 2023. Warszawa: Ministerstwo Infrastruktury i Rozwoju. Retrieved 2.09.2019 from https://www.funduszeeuropejskie. gov.pl/media/74967/Krajowa_Polityka_Miejska_2023.pdf

Miszczak, K. (2012a). Dylematy rozwoju regionu ekonomicznego w świetle wyzwań XXI wieku. Wrocław: Wydawnictwo Uniwersytetu Ekonomicznego we Wrocławiu.

Miszczak, K. (2012b). Rozwój nowoczesnej działalności gospodarczej w mieście jako cel polityki przestrzennej. In M. J. Nowak, and T. Skotarczak (Eds.), Zarządzanie przestrzenia miasta (pp. 99-127). Warszawa: Wydawnictwo CeDeWu.

Miszczak, K. (2017). Wrocław miastem odpornym na kryzys? Prace Naukowe Uniwersytetu Ekonomicznego we Wroctawiu, (490), 134-147.

Okoń-Horodyńska, E. (1996). Instytucjonalne podejście w analizie procesów społeczno-gospodarczych i politycznych w Polsce. Katowice: Wydawnictwo Akademii Ekonomicznej w Katowicach.

Osborne, D., and Gaebler, T. (1994). Rządzić inaczej. Jak duch przedsiębiorczości przenika i przekształca administrację publiczna. Poznań: Media Rodzina.

Patel, R. (2010). Wartość niczego. Jak przekształcić społeczeństwo rynkowe i na nowo zbudować demokrację. Warszawa: Wydawnictwo Muza.

Polanyi, K. (1944). The great transformation. The political and economic origins of time, New York: Rinehart and Company.

Rousseau, J. M. (2008). Europejskie regiony w kontekście globalnej bitwy o przyszłość. In P. Jakubowska, A. Kukliński, and P. Żuber (Eds.), Problematyka przyszłości regionów. W poszukiwaniu nowego paradygmatu. Warszawa: Wydawnictwo Ministerstwa Rozwoju Regionalnego.

Scott, A. J. (1993). Technopolis. High-technology industry and regional development in Southern California. Berkeley, CA: University of California Press.

Scott, A. J. (2010). Cultural economy and the creative field of the city. Human Geography, 92(2), 115-130.

Sokołowicz, M. E. (2015). Rozwój terytorialny w świetle dorobku ekonomii instytucjonalnej. Przestrzeń - bliskość - instytucje. Łódź: Wydawnictwo Uniwersytetu Łódzkiego. 
Sörensen, E. (2005), The democratic problems and potentials of network governance. European Political Science, (4), 348-357.

Stawasz, D. (2017). Ekonomia instytucjonalna wobec problemu rozwoju miasta. Biuletyn KPZK PAN, (265), 19.

Walts, M. J. (1996). State of cluster - based economic development in Arizona. In R. Breault (Ed.), Global networking of regional optics clusters. Denver, Colorado: The International Society for Optical Engineering.

Wojciechowski, E., and Podgórniak-Krzykacz A. (2007). Governance jako nowy sposób zarządzania sprawami publicznymi. In J. Sokołowski, and Z. Przybyła (Eds.), Współczesne problemy polityki ekonomicznej. Jelenia Góra: Wydawnictwo Akademii Ekonomicznej we Wrocławiu. 